Proceedings

\title{
Cytotoxic Effect of Cholesterol Metabolites on Human Colonic Tumor (Caco-2) and Non-Tumor (CCD-18Co) Cells and Their Potential Implication in Colorectal Carcinogenesis ${ }^{\dagger}$
}

\author{
Mussa Makran, Gabriel López-García, Guadalupe Garcia-Llatas, Reyes Barberá, Amparo Alegría \\ and Antonio Cilla *
}

Citation: Makran, M.; López-García, G.; Garcia-Llatas, G.; Barberá, R.; Alegría, A. Cytotoxic Effect of Cholesterol Metabolites on Human Colonic Tumor (Caco-2) and Non-Tumor (CCD-18Co) Cells and Their Potential Implication in Colorectal Carcinogenesis. Proceedings 2021, 70, 56. https://doi.org/10.3390/ foods_2020-07613

Published: 9 November 2020

Publisher's Note: MDPI stays neutral with regard to jurisdictional claims in published maps and institutional affiliations.

Copyright: () 2020 by the authors. Licensee MDPI, Basel, Switzerland. This article is an open access article distributed under the terms and conditions of the Creative Commons Attribution (CC BY) license (http://creativecommons.org/licenses/by/4.0/).

\author{
Nutrition and Food Science Area, Faculty of Pharmacy, University of Valencia, Av, Vicente Andrés Estellés \\ s/n, 46100 Burjassot, Spain; Mussa.Makran@uv.es (M.M.); Gabriel.lopez@uv.es (G.L.-G.); \\ Guadalupe.Garcia@uv.es (G.G.-L.); Reyes.Barbera@uv.es (R.B.); Amparo.Alegria@uv.es (A.A.) \\ * Correspondence: Antonio.Cilla@uv.es; Tel.: +34-963-544-972 \\ + Presented at the 1st International Electronic Conference on Food Science and Functional Foods, \\ 10-25 November 2020; Available online: https://foods_2020.sciforum.net/.
}

\begin{abstract}
Unabsorbed cholesterol, along with that of bile secretions and flaked colon cells, can be metabolized by colonic microbiota. The generated metabolites have been proposed as promoters of colorectal cancer (CRC). In this study, the cytotoxicity (MTT assay) of the main commercially available cholesterol-derived metabolites (coprostanol, cholestanol, coprostanone, and cholestenone) on human colon cancer (Caco-2) and non-tumor (CCD-18Co) cells was evaluated at different physiologically relevant concentrations $(9.4-300 \mu \mathrm{M})$ and incubation times (24-72 h). In general, the metabolites that most reduced cell viability were coprostanone (54-85\% in Caco-2 and $20-81 \%$ in CCD$18 \mathrm{Co}$ ) and cholestenone (17-91\% in Caco-2 and 14-81\% in CCD-18Co). These two metabolites are the most hydrophobic, thus reflecting a possible relationship between hydrophobicity and cytotoxicity. Moreover, cholestenone ( $\mathrm{IC}_{50}$ at $72 \mathrm{~h}: 5 \pm 1 \mu \mathrm{g} / \mathrm{mL}$ ) should be considered cytotoxic on CCD18Co cells (non-tumor cells) since it shows an $\mathrm{IC}_{50}$ close to the one considered toxic $(<4 \mu \mathrm{g} / \mathrm{mL})$. Furthermore, CCD-18Co cells are more vulnerable to the cytotoxic effect of cholesterol metabolites. Possible compensatory responses, attenuating the reduction in cell viability caused by cholesterol metabolites, were observed, however these reactions could favor inflammation, resistance to apoptosis, and cellular proliferation, likely contributing to the development of CRC. In conclusion, cholesterol metabolites, mainly the most hydrophobic, could act as promoters of CRC through their cytotoxic activity.
\end{abstract}

Keywords: colorectal cancer; cytotoxicity; cholesterol metabolites; Caco-2 cells; CCD-18Co cells

\section{Introduction}

Colorectal cancer (CRC) was the second most prevalent cancer in the world in 2018 and the second cause of cancer-related death worldwide [1]. Some authors propose that diets rich in fats and proteins of animal origin are related to an increased risk of CRC through an increase in the production of cholesterol-derived metabolites by the intestinal microbiota [2,3]. Since cytotoxicity may be a mechanism in cancer induction [4], the objective of the present study was to evaluate the cytotoxic activity of the main commercially available cholesterol-derived metabolites (coprostanol, cholestanol, coprostanone, and cholestenone) on undifferentiated human colonic epithelial adenocarcinoma cells (Caco-2) and non-tumor human colon fibroblasts (CCD-18Co). 


\section{Results}

Cytotoxic effect of cholesterol metabolites and 5-fluorouracil (5-FU) on CCD-18Co and Caco-2 cells is shown in Table 1.

Table 1. Cytotoxicity assay with metabolites of cholesterol and 5-fluorouracil (5-FU) in CCD-18Co and Caco-2 cells.

\begin{tabular}{|c|c|c|c|c|c|c|}
\hline \multirow[b]{3}{*}[\mu\mathrm{M}]{} & \multicolumn{6}{|c|}{ Cell Viability (\% Control) } \\
\hline & \multicolumn{3}{|c|}{ CCD-18Co } & \multicolumn{3}{|c|}{ Caco-2 } \\
\hline & $24 \mathrm{~h}$ & $48 \mathrm{~h}$ & $72 \mathrm{~h}$ & $24 \mathrm{~h}$ & $48 \mathrm{~h}$ & $72 \mathrm{~h}$ \\
\hline \multicolumn{7}{|l|}{ Coprostanol } \\
\hline 9.4 & $98 \pm 6$ abA & $90 \pm 2 \mathrm{aA} \neq$ & $93 \pm 3$ aA & $106 \pm 15 \mathrm{aA}$ & $105 \pm 4$ aA & $108 \pm 15 \mathrm{abA}$ \\
\hline 18.75 & $103 \pm 4^{\mathrm{bA}}$ & $97 \pm 3 \mathrm{abA} \ddagger$ & $109 \pm 9 \mathrm{aA}$ & $109 \pm 22 \mathrm{aA}$ & $117 \pm 4^{* \mathrm{bA}}$ & $105 \pm 8$ abA \\
\hline 37.5 & $109 \pm 3^{b A}$ & $91 \pm 5 \mathrm{aB} \ddagger$ & $101 \pm 2 \mathrm{aAB}$ & $93 \pm 6^{\mathrm{aA}}$ & $102 \pm 2 \mathrm{aAB}$ & $121 \pm 15 \mathrm{bcB}$ \\
\hline 75 & $101 \pm 7 \mathrm{abA}$ & $106 \pm 4 \mathrm{bA}$ & $99 \pm 19$ aA & $108 \pm 9 \mathrm{aA}$ & $102 \pm 7$ aA & $111 \pm 17 \mathrm{abA}$ \\
\hline 150 & $100 \pm 8 \mathrm{abA} \ddagger$ & $89 \pm 7 \mathrm{aAB} \ddagger$ & $84 \pm 7 \mathrm{aB} \ddagger$ & $137 \pm 8^{\mathrm{aA}}$ & $132 \pm 4 *_{\mathrm{CA}}$ & $142 \pm 9 * \mathrm{cA}$ \\
\hline 300 & $89 \pm 4$ aA $\neq$ & $72 \pm 6^{* \mathrm{cB} \ddagger}$ & $48 \pm 5 * \mathrm{aC} \neq$ & $146 \pm 54$ aA & $103 \pm 3$ aв & $90 \pm 10$ авС \\
\hline \multicolumn{7}{|l|}{ Cholestanol } \\
\hline 9.4 & $86 \pm 13$ aA & $79 \pm 8^{* a A}$ & $93 \pm 22 \mathrm{aA}$ & $86 \pm 11^{\mathrm{aA}}$ & $96 \pm 1^{\text {aA }}$ & $94 \pm 22 \mathrm{aA}$ \\
\hline 18.75 & $72 \pm 7$ *abA & $74 \pm 5^{* a A \ddagger}$ & $84 \pm 12$ aA & $86 \pm 10 \mathrm{aA}$ & $102 \pm 2 \mathrm{aA}$ & $93 \pm 16^{\mathrm{aA}}$ \\
\hline 37.5 & $70 \pm 4^{* a b A}$ & $73 \pm 9 *^{* A \neq}$ & $80 \pm 10^{\mathrm{aA}}$ & $80 \pm 8 * a A$ & $90 \pm 10^{a A}$ & $99 \pm 27 \mathrm{aA}$ \\
\hline 75 & $67 \pm 8^{* a b A}$ & $75 \pm 5{ }^{* a A}$ & $77 \pm 4^{\mathrm{aA}}$ & $76 \pm 4 * a A$ & $92 \pm 9 \mathrm{aA}$ & $80 \pm 9$ aA \\
\hline 150 & $61 \pm 9 * \mathrm{bA} \ddagger$ & $70 \pm 5^{* a A \ddagger}$ & $75 \pm 4^{\mathrm{aA}}$ & $77 \pm 3 *_{\mathrm{aA}}$ & $91 \pm 2^{\mathrm{aAB}}$ & $104 \pm 17$ ав \\
\hline 300 & $59 \pm 10$ *bA & $72 \pm 5^{* a A \ddagger}$ & $98 \pm 15$ aB & $79 \pm 1 * a A$ & $97 \pm 2^{\mathrm{aAB}}$ & $108 \pm 24$ aв \\
\hline \multicolumn{7}{|l|}{ Coprostanone } \\
\hline 9.4 & $94 \pm 10^{\mathrm{aA}}$ & $101 \pm 11 \mathrm{aA}$ & $80 \pm 2 * a B \ddagger$ & $90 \pm 18$ aA & $106 \pm 11 \mathrm{abA}$ & $105 \pm 16^{\mathrm{aA}}$ \\
\hline 18.75 & $107 \pm 15 \mathrm{aA}$ & $91 \pm 5 \mathrm{aB} \neq$ & $86 \pm 15 \mathrm{aB}$ & $115 \pm 11$ aA & $127 \pm 6$ *bA & $115 \pm 4 \mathrm{aA}$ \\
\hline 37.5 & $87 \pm 11^{\mathrm{aA}}$ & $100 \pm 4^{\mathrm{aA} \ddagger}$ & $66 \pm 9 * a B+$ & $108 \pm 29 \mathrm{aA}$ & $120 \pm 13 \mathrm{bA}$ & $112 \pm 9 \mathrm{aA}$ \\
\hline 75 & $65 \pm 2 * \mathrm{bA} \ddagger$ & $99 \pm 8^{a B \ddagger}$ & $47 \pm 8 * \mathrm{bC} \neq$ & $132 \pm 16^{\mathrm{aA}}$ & $123 \pm 10 * \mathrm{bA}$ & $102 \pm 7 \mathrm{aA}$ \\
\hline 150 & $62 \pm 6$ *bcA & $52 \pm 13 * \mathrm{bA} \neq$ & $25 \pm 1 *_{\mathrm{cB}}$ & $106 \pm 8^{\mathrm{aA}}$ & $117 \pm 6^{\mathrm{bA}}$ & $46 \pm 3 * \mathrm{bB}$ \\
\hline 300 & $44 \pm 3 * \mathrm{cA} \neq$ & $25 \pm 3 *_{\mathrm{cB} \neq}$ & $19 \pm 4 *^{* \mathrm{~B}}$ & $103 \pm 16^{\mathrm{aA}}$ & $95 \pm 9$ aA & $15 \pm 3 * \mathrm{cB}$ \\
\hline \multicolumn{7}{|l|}{ Cholestenone } \\
\hline 9.4 & $86 \pm 4$ *aA & $90 \pm 7$ aA & $61 \pm 31 *_{\mathrm{aB}}$ & $83 \pm 3$ *aA & $93 \pm 5$ aA & $83 \pm 19$ aA \\
\hline 18.75 & $76 \pm 5 * \mathrm{bA}$ & $82 \pm 5^{*_{\mathrm{aA}}}$ & $51 \pm 25^{* a b B \neq}$ & $70 \pm 5^{* \mathrm{bA}}$ & $77 \pm 2 * \mathrm{bA}$ & $81 \pm 7 \mathrm{abA}$ \\
\hline 37.5 & $56 \pm 4 *^{* A \ddagger}$ & $81 \pm 19 *_{\mathrm{aB}}$ & $61 \pm 4 *_{\mathrm{aA}}$ & $70 \pm 5 * \mathrm{bA}$ & $68 \pm 6 * \mathrm{bA}$ & $61 \pm 10 * \mathrm{bA}$ \\
\hline 75 & $37 \pm 3 * \mathrm{dA} \neq$ & $21 \pm 3 * \mathrm{bA} \neq$ & $21 \pm 2 * \mathrm{bA}$ & $60 \pm 7$ *bA & $51 \pm 5 *_{\mathrm{cA}}$ & $27 \pm 3 *_{\mathrm{cB}}$ \\
\hline 150 & $27 \pm 2 *_{\mathrm{eA}} \neq$ & $19 \pm 2 * \mathrm{bA}$ & $24 \pm 5^{* a \mathrm{abA}}$ & $37 \pm 6 * \mathrm{cA}$ & $17 \pm 1 * \mathrm{~dB}$ & $10 \pm 3 *_{\mathrm{CB}}$ \\
\hline 300 & $29 \pm 3 * \mathrm{deA}$ & $19 \pm 1$ *bA & $31 \pm 10 * a b A$ & $29 \pm 3 *_{\mathrm{CA}}$ & $12 \pm 2 * \mathrm{~dB}$ & $9 \pm 1 *^{* \mathrm{~B}}$ \\
\hline 5-Fluorouracil (25 $\mu \mathrm{M})$ & $90 \pm 3$ *aA & $65 \pm 5$ *bA & $64 \pm 2 * \mathrm{bA}$ & $64 \pm 10 * a \mathrm{~B}$ & $70 \pm 10^{* a A}$ & $67 \pm 7^{* a A}$ \\
\hline
\end{tabular}

Data are shown as mean \pm standard deviation $(n=4)$. The asterisk indicates statistically significant differences $(p<0.05)$ between the treatments and the control. Different lowercase letters (a-e) indicate statistically significant differences $(p<$ 0.05 ) at different concentrations for the same incubation time, cell line, and cytotoxic agent. Different capital letters (A-C) indicate statistically significant differences $(p<0.05)$ at different times at the same concentration, cell line, and cytotoxic agent. The $\ddagger$ sign indicates a statistically significant difference $(p<0.05)$ vs. Caco-2 cells at the same concentration, incubation time, and cytotoxic agent.

\subsection{Coprostanol}

After treatment with coprostanol a reduction in the viability of CCD-18Co cells was observed at $300 \mu \mathrm{M}$ after $48 \mathrm{~h}$ ( $28 \%$ vs. control) and $72 \mathrm{~h}$ ( $52 \%$ vs. control). However, Caco2 cells did not experience a reduction in viability, whilst an increase in cell viability was observed at 18.75 and $150 \mu \mathrm{M}$ (117 and 132\% vs. control, respectively). This fact could indicate a possible hyperproliferative response to the toxic effect of coprostanol. Therefore, the Caco-2 cells could be less susceptible to the cytotoxicity of coprostanol and could be capable of making a compensatory response earlier. 


\subsection{Cholestanol}

The incubation of cholestanol for $24 \mathrm{~h}$, at concentrations of $18.75 \mu \mathrm{M}$ or above, reduces statistically $(p<0.05)$ CCD-18Co cells viability ( $28-41 \%$ vs. control), whilst at $48 \mathrm{~h}$ a cell viability reduction at all concentrations is observed (21-30\% vs. control). At $72 \mathrm{~h}$, a reduction in the viability of CCD-18Co cells is not observed, which could indicate a possible compensatory response. This response is verified by observing that the reductions in cell viability at $300 \mu \mathrm{M}$ decrease with time $(41,28$, and $2 \%$ vs. control at 24,48 , and 72 $\mathrm{h}$, respectively). In addition, in Caco- 2 cells, cholestanol at $24 \mathrm{~h}$ reduces the cell viability from $37.5 \mu \mathrm{M}(20-24 \%$ vs. control), without effect at 48 and $72 \mathrm{~h}$. Therefore, compensatory response is again observed (earlier than in CCD-18Co cells), which is confirmed with cell viability values after $72 \mathrm{~h}$ at 150 (104\% vs. control) and $300 \mu \mathrm{M}$ (108\% vs. control) higher than $24 \mathrm{~h}$ (77 and 79\% vs. control, respectively). On the other hand, the CCD-18Co cells are more susceptible since the reduction in cell viability at 150 and $300 \mu \mathrm{M}$ after $24 \mathrm{~h}$ is greater than that observed in Caco-2 cells ( 39 vs. $23 \%$ control; 41 vs. $21 \%$ control, respectively).

\subsection{Coprostanone}

Coprostanone at $24 \mathrm{~h}$ significantly reduced the viability of CCD-18Co cells from 75 $\mu \mathrm{M}(35-56 \%$ vs. control), at $48 \mathrm{~h}$ from $150 \mu \mathrm{M}(48-75 \%$ vs. control), and at $72 \mathrm{~h}$ at all concentrations except $18.75 \mu \mathrm{M}(20-81 \%$ vs. control). A time-response relationship was observed, with an increase in the reduction of viability with time at 150 and $300 \mu \mathrm{M}$. In Caco2 cells, coprostanone did not reduce cell viability at $24-48 \mathrm{~h}$, and only at $72 \mathrm{~h}$ a reduction of cell viability from $150 \mu \mathrm{M}$ (54-85\% vs. control) was observed.

\subsection{Cholestenone}

In general, the incubation of cholestenone at $24 \mathrm{~h}$ reduced CCD-18Co (14-73\% vs. control) and Caco-2 cells (17-71\% vs. control) viability at all concentrations investigated in a dose-dependent manner. The effect at $48 \mathrm{~h}$ was slightly lower for both cell lines (18$81 \%$ and $23-88 \%$ vs. control, respectively), since the minimum dose required was 18.75 $\mu \mathrm{M}$. At $72 \mathrm{~h}$, cholestanone produced a similar cell viability reduction in CCD-18Co cells (39-79\% vs. control) compared to $48 \mathrm{~h}$, but in Caco-2 cells a dose $\geq 37.5 \mu \mathrm{M}$ was necessary to produce a cell viability reduction (39-91\% vs. control). The effect of the cholestenone on cell viability was time-dependent for certain conditions. In this regard, in the CCD18Co cells there is a higher reduction of cell viability at 9.4 and $18.75 \mu \mathrm{M}$ at $72 \mathrm{~h}$, and in the Caco-2 cells at 75, 150 and $300 \mu \mathrm{M}$ at $72 \mathrm{~h}$. In addition, it appears that Caco- 2 cells give a compensatory response at 9.4 and $18.75 \mu \mathrm{M}$ with a trend of lower cell viability decrease at 48 and $72 \mathrm{~h}$.

\subsection{5-Fluorouracil}

5-FU reduced the cell viability of both cell lines at all incubation times (CCD18-Co: $10-36 \%$; Caco-2: $30-36 \%$ vs. control). The reduction in the viability of Caco-2 cells was not time-dependent, while in the non-tumor line the effect increased with time $(24-48<72 \mathrm{~h})$. Regarding the sensitivity of the cell lines, only at $24 \mathrm{~h}$ was the reduction in cell viability more pronounced in the Caco- 2 vs. CCD-18Co cells (36 vs. 10\% control), although these differences were not statistically significant $(p<0.05)$ at 48 and $72 \mathrm{~h}$.

\section{Discussion}

The cholesterol that reaches the colon can be metabolized by the colonic microbiota (mainly bacteria of the genus Eubacterium and Bacteroides) [5]. There are studies which have observed that subjects with CRC present a significantly higher fecal concentration (vs. control) of cholesterol metabolites ( $21.1 \mathrm{vs.} 14.5 \mathrm{mg} / \mathrm{g}$ dry feces) [3]. The authors attribute these observations to the abundance of anaerobic bacteria capable of metabolizing cholesterol to potential CRC promoters, and attribute the differences in intestinal flora to 
the composition of the diet [2,3]. The cytotoxicity may be a key mechanism in cancer induction [4], therefore, in the present study, the cytotoxic activity of the coprostanol, cholestanol, coprostanone, and cholestenone on Caco-2 and CCD-18Co cells was evaluated.

A pure compound is cytotoxic when the half maximal inhibitory concentration (IC 50 ) value is less than $4 \mu \mathrm{g} / \mathrm{mL}$ after $48-72 \mathrm{~h}$ of incubation [6]. Based on this, cholestenone (IC50 at $72 \mathrm{~h}: 5 \pm 1 \mu \mathrm{g} / \mathrm{mL}$ ) would be considered cytotoxic on CCD-18Co cells. Studies in rats indicate that cholestenone induces nuclear aberrations [7] and exchange of sister chromatids [8] in the colonic epithelium. These data suggest that cholestenone could be the metabolite with the greatest capacity to promote CRC. Furthermore, coprostanone is the second most cytotoxic metabolite ( $\mathrm{IC}_{50}$ at $72 \mathrm{~h}: 15.9-46.8 \mu \mathrm{g} / \mathrm{mL}$ ). Therefore, the two most cytotoxic metabolites are, in turn, the most hydrophobic. Probably the greater hydrophobicity favors the ability to alter the structure of the cell membrane and thereby generate cell damage, as occurs with secondary bile acids (promoters of colorectal carcinogenesis, structurally similar to cholesterol metabolites) [9]. In contrast, coprostanol and cholestanol are the metabolites with the lowest cytotoxic activity. In the case of coprostanol, the equatorial position of the C-3 hydroxyl group reduces the ability of coprostanol to bind to the cell membranes of the colon, which would facilitate its elimination through the feces [10].

On other hand, it was observed that CCD-18Co cells are more sensitive to the cytotoxicity of cholesterol metabolites. In other studies, it was also observed that the viability of certain tumor lines (human esophageal, gastric and colorrectal, and mouse colorectal) is not affected by cholestanol [11,12], observing, instead, a slight reduction in the viability of non-tumor human esophageal cells [11]. If cholesterol metabolites exert their cytotoxicity by inducing oxidative stress, such as secondary bile acids [13], one possible reason why CCD-18Co cells are more vulnerable to metabolite cytotoxicity can be related to the antioxidant status. The Caco-2 cells are thought to exhibit high intracellular ferritin (antioxidant) levels due to exposure to the heme group through mucosal bleeding and dietary protein during neoplasia [14]. So, the ferritin content in Caco-2 cells is likely to be higher than that of CCD-18Co cells, which would provide protection against possible oxidative damage of cholesterol metabolites. In addition, the composition of the plasma membrane could also be responsible for the difference in the sensitivity of cell lines to metabolites. During colon carcinogenesis, tumor cells undergo changes that allow them to acquire resistance to hydrophobic cytotoxic agents, through an increase in the expression of adenosine triphosphate-binding cassette transporters $(A B C)$, membrane proteins that induce the efflux of substances toxic to cells [15]. Given that these transporters are involved in the efflux of cholesterol and plant sterols from the enterocyte to the intestinal lumen [16], it would be plausible to think that they may also act as transporters for metabolites, making Caco-2 cells less sensitive to their toxicity. In summary, Caco-2 cells are less sensitive to the cytotoxicity of cholesterol metabolites due to their higher antioxidant status and expression in $\mathrm{ABC}$ transporters.

It was observed that the reduction in cell viability decreased in some cases with time, which could indicate that the cells adopt a compensatory response. As occurs when cells are exposed to secondary bile acids, the toxic effect of metabolites could lead to the activation of nuclear factor-kappa B (NF- $\kappa B$ ) [17]. It is known that NF- $k B$ is a transcriptional regulator that increases the expression of genes that encode antioxidant enzymes and $A B C$ transporter, stimulates cell proliferation, induces resistance to apoptosis, and is related to inflammatory processes [18]. Therefore, a hyperproliferative and antioxidant response, together with an increase in the expression of $\mathrm{ABC}$ protein and resistance to apoptosis, would explain the lower reduction in cell viability observed. Furthermore, the increase in cell proliferation, resistance to apoptosis and inflammation could be the mechanisms through which cholesterol metabolites are involved in colorectal tumorigenesis, as occurs with secondary bile acids [13]. Furthermore, it was observed that the compensatory response in Caco-2 cells could occur much earlier than in the non-tumor line. The higher proliferative activity of Caco-2 cells, together with their higher antioxidant status [14] and 
the higher expression of $\mathrm{ABC}$ proteins [15], would explain why the compensatory response of Caco-2 cells occurred earlier than in CCD-18Co cells.

\section{Materials and Methods}

Caco-2 (passages: 10-17) and CCD-18Co (passages: 3-9) cells come from American Type Culture Collection (HTB-37 and CRL-1459, respectively) (Rockville, MD, USA). Both cells line were seeded at a density of 25,000 cells/well in 96-well plates and incubated at $37^{\circ} \mathrm{C}$, at $95 \%$ relative humidity and with $5 \%(v / v)$ of $\mathrm{CO}_{2}$. At $24 \mathrm{~h}$ post-seeding, the cells were treated with metabolites individually at different concentrations $(9.4,18.75,37.5,75$, 150 , and $300 \mu \mathrm{M}$ ) and incubated for 24,48 , and $72 \mathrm{~h}$.

Untreated cells were the control and 5-FU $(25 \mu \mathrm{M})$, a well-known cytotoxic agent on human colon cancer cells [19]. The cytotoxic activity of metabolites on Caco-2 and CCD18Co cells was evaluated by the methylthiazolyldiphenyl-tetrazolium bromide (MTT) assay. Briefly, after treatment with metabolites, the culture medium was removed and 90 $\mu \mathrm{L}$ of phosphate-buffered saline (PBS) and $10 \mu \mathrm{L}$ of MTT $(0.5 \mathrm{mg} / \mathrm{mL}$ in PBS) added. After $4 \mathrm{~h}$ of incubation, the MTT solution was removed and the formazan salts solubilized with $10 \mu \mathrm{L}$ of dimethylsulfoxide. Formazan formation was determined by spectrophotometry at $570 \mathrm{~nm}$ with background subtraction at $690 \mathrm{~nm}$.

\section{Conclusions}

The metabolites produced by intestinal bacteria from cholesterol, mainly those of a hydrophobic nature (cholestenone and coprostanone), could be involved in colorectal carcinogenesis through their cytotoxic activity. More in-depth biochemical and molecular assays are needed to decipher the specific mechanisms involved in their deleterious activity.

Author Contributions: Conceptualization, G.G.-L., R.B., A.A., and A.C.; investigation, M.M. and G.L.-G.; writing-original draft preparation, M.M.; supervision, G.L.-G., G.G.-L., R.B., A.A., and A.C. All authors have read and agreed to the published version of the manuscript.

Funding: Authors thank the financial support from project PID2019-104167RB-I00/AEI/10.13039/501 100011033 (Ministry of Science and Innovation, Spain). M.M. holds an FPU19/00156 grant from the Ministry of Universities (Spain). G.L.-G holds a junior doctor researcher contract within the aforementioned project (CPI-17-025).

Institutional Review Board Statement: Not applicable.

Informed Consent Statement: Not applicable.

Data Availability Statement: The data presented in this study are available on request from the corresponding author.

Conflicts of Interest: The authors declare no conflict of interest. The funders had no role in the Informed Consent Statement.

\section{Abbreviations}

The following abbreviations are used in this manuscript:

$\mathrm{ABC}$ Adenosine triphosphate-binding cassette

CRC Colorectal cancer

5-FU 5-Fluorouracil

IC 50 Half maximal inhibitory concentration

MTT Methylthiazolyldiphenyl-tetrazolium bromide

NF- $\kappa B \quad$ Nuclear factor-kappa B

PBS Phosphate-buffered saline 


\section{References}

1. Rawla, P.; Sunkara, T.; Barsouk, A. Epidemiology of colorectal cancer: Incidence, mortality, survival, and risk factors. Prz. Gastroenterol. 2019, 14, 89, doi:10.5114/pg.2018.81072.

2. Hill, M.J.; Drasar, B.S.; Aries, V.; Crowther, J.S.; Hawksworth, G.; Williams, R.E.O. Bacteria and aetiology of cancer of large bowel. Lancet 1971, 297, 95-100, doi:10.1016/S0140-6736(71)90837-3.

3. Reddy, B.S.; Wynder, E.L. Metabolic epidemiology of colon cancer: Fecal bile acids and neutral sterols in colon cancer patients and patients with adenomatous polyps. Cancer 1977, 39, 2533-2539, doi:10.1002/1097-0142(197706)39:6\%3C2533::AIDCNCR2820390634\%3E3.0.CO;2-X.

4. Butterworth, B.E.; Bogdanffy, M.S. A comprehensive approach for integration of toxicity and cancer risk assessments. Regul. Toxicol. Pharmacol. 1999, 29, 23-36, doi:10.1006/rtph.1998.1273.

5. Cuevas-Tena, M.; Alegría, A.; Lagarda, M.J. Relationship between dietary sterols and gut microbiota: A review. Eur. J. Lipid Sci. Technol. 2018, 120, 1800054, doi:10.1002/ejlt.201800054.

6. López-García, G.; Alegría, A.; Barberá, A.; Cilla, A. Antiproliferative Effects and Mechanism of Action of Phytosterols Derived from Bioactive Plant Extracts. In Nutraceuticals and Natural Product Derivatives: Disease Prevention E Drug Discovery, 1st ed.; Ullah, M.F., Ahmad, A., Eds.; John Wiley \& Sons, Inc.: Hoboken, NJ, USA, 2019; pp. 145-165, doi:10.1002/9781119436713.ch7.

7. Suzuki, K.; Bruce, W.R.; Baptista, J.; Furrer, R.; Vaughan, D.J.; Krepinsky, J.J. Characterization of cytotoxic steroids in human faeces and their putative role in the etymology of human colonic cancer. Cancer Lett. 1986, 33, 307-316, doi:10.1016/03043835(86)90070-4.

8. Kaul, H.K.; Couch, D.B.; Gingerich, J.D.; Bruce, W.R.; Heddle, J.A. Genotoxicity of two fecal steroids in murine colonic epithelium assessed by the sister chromatid exchange technique. Mutagenesis 1987, 2, 441-444, doi:10.1093/mutage/2.6.441.

9. Araki, Y.; Andoh, A.; Bamba, H.; Yoshikawa, K.; Komai, Y.; Higuchi, A.; Fujiyama, Y. The cytotoxicity of hydrophobic bile acids is ameliorated by more hydrophilic bile acids in intestinal cell lines IEC-6 and Caco-2. Oncol. Rep. 2003, 10, 1931-1936, doi:10.3892/or.10.6.1931.

10. Kriaa, A.; Bourgin, M.; Mkaouar, H.; Jablaoui, A.; Akermi, N.; Soussou, S.; Maguin, E.; Rhimi, M. Microbial reduction of cholesterol to coprostanol: An old concept and new insights. Catalysts 2019, 9, 167, doi:10.3390/catal9020167.

11. Faried, A.; Faried, L.S.; Nakagawa, T.; Yamauchi, T.; Kitani, M.; Sasabe, H.; Nishimura, T.; Usman, N.; Kato, H.; Asao, T.; et al. Chemically synthesized sugar-cholestanols possess a preferential anticancer activity involving promising therapeutic potential against human esophageal cancer. Cancer Sci. 2007, 98, 1358-1367, doi:10.1111/j.1349-7006.2007.00563.x.

12. Hahismoto, S.; Yazawa, S.; Asao, T.; Faried, A.; Nishimura, T.; Tsuboi, K.; Nakagawa, T.; Yamauchi, T.; Koyama, N.; Umehara, K.; et al. Novel sugar-cholestanols as anticancer agents against peritoneal dissemination of tumor cells. Glycoconj. J. 2008, 25, 531-544, doi:10.1007/s10719-008-9108-x.

13. Ajouz, H.; Mukherji, D.; Shamseddine, A. Secondary bile acids: An underrecognized cause of colon cancer. World J. Surg. Oncol. 2014, 12, 1-5, doi:10.1186/1477-7819-12-164.

14. Cermak, J.; Balla, J.; Jacob, H.S.; Balla, G.; Enright, H.; Nath, K.; Vercellotti, G.M. Tumor cell heme uptake induces ferritin synthesis resulting in altered oxidant sensitivity: Possible role in chemotherapy efficacy. Cancer Res. 1993, 53, 5308-5313.

15. Lin, Y.; Bai, L.; Chen, W.; Xu, S. The NF- $\kappa B$ activation pathways, emerging molecular targets for cancer prevention and therapy. Expert Opin. Ther. Targets 2010, 14, 45-55, doi:10.1517/14728220903431069.

16. Von Bergmann, K.; Sudhop, T.; Lütjohann, D. Cholesterol and plant sterol absorption: Recent insights. Am. J. Cardiol. 2005, 96, 10-14, doi:10.1016/j.amjcard.2005.03.014.

17. Payne, C.M.; Weber, C.; Crowley-Skillicorn, C.; Dvorak, K.; Bernstein, H.; Bernstein, C.; Holubec, H.; Dvorakova, B.; Garewal, $\mathrm{H}$. Deoxycholate induces mitochondrial oxidative stress and activates NF- $\kappa \mathrm{B}$ through multiple mechanisms in HCT-116 colon epithelial cells. Carcinogenesis 2007, 28, 215-222, doi:10.1093/carcin/bgl139.

18. Jarosz, M.; Olbert, M.; Wyszogrodzka, G.; Młyniec, K.; Librowski, T. Antioxidant and anti-inflammatory effects of zinc. Zinc-

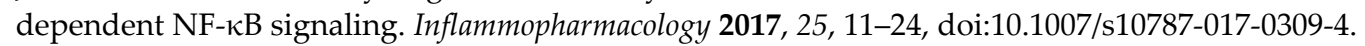

19. Álvarez-Sala, A.; Ávila-Gálvez, M.A.; Cilla, A.; Barberá, R.; Garcia-Llatas, G.; Espín, J.C.; González-Sarrías, A. Physiological concentrations of phytosterols enhance the apoptotic effects of 5-fluorouracil in colon cancer cells. J. Funct. Foods 2018, 49, 5260, doi:10.1016/j.jff.2018.08.016. 